Cerebrovascular Diseases 中文目录 2006 年第 21 卷第 1-2 期

Table of Contents Vol.21, No. 1-2, 2006

翻译 许剑 审校 刘新峰 徐格林 (南京军区南京总医院神经内科, 南京大学医学院)

Translated by Jian Xu and supervised by Xinfeng Liu, Gelin Xu, Dept. Neurology, Nanjing Jinling Hospital, School of Medicine, Nanjing University

目前此翻译内容仅包括自 2004 年以来的《脑血管病》杂志目录。

For the moment, this translation service includes only the Table of Contents from

CEREBROVASCULAR DISEASES and starts with the first issue of the year 2004.

\title{
文书 Paper
}

1 来自编辑的信息

Message from the Editors

Hennerici, M.G. ; Bogousslavsky, J.

Cerebrovasc Dis 2006;21:1-3

\section{4 编者述评}

Editorial

Mohr, J.P.

Cerebrovasc Dis 2006;21:4-5

\section{综述Review}

6 卒中康复的病理生理学: 影响神经功能恢复的时间因素

Pathophysiology of Stroke Rehabilitation: Temporal Aspects of Neurofunctional Recovery

Kreisel, S.H. ; Bäzner, H. ; Hennerici, M.G.

Cerebrovasc Dis 2006;21:6-17

\section{论著Original Paper}

18 原发性抄内出血的危险因素

Risk Factors for Primary Intracerebral Hemorrhage

Zia, E. ; PessahRasmussen, H. ; Khan, F.A. ; Norrving, B. ; Janzon, L. ; Berglund, G. ; Engström, G.

Cerebrovasc Dis 2006;21:18-25

\section{6 主动脉弓中度粥样斑块形成与卒中危险性}

Moderate Atheroma of the Aortic Arch and the Risk of Stroke

Tanaka, M. ; Yasaka, M. ; Nagano, K. ; Otsubo, R. ; Oe, H. ; Naritomi, H.

Cerebrovasc Dis 2006;21:26-

\section{2 早期脑卒中患者血清中的核小体}

Nucleosomes in Serum of Patients with Early Cerebral Stroke

Geiger, S. ; Holdenrieder, S. ; Stieber, P. ; Hamann, G.F. ; Bruening, R. ; Ma, J. ; Nagel, D. ; Seidel, D.

Cerebrovasc Dis 2006;21:32-37

\section{8 成年镰状红细胞病患者的经妙多普勒超声检查}

Transcranial Doppler in Adult Patients with Sickle Cell Disease

Sampaio Silva, G. ; Vicari, P. ; Figueiredo, M.S. ; Filho, A.C. ; Valadi, N. ; Massaro, A.R.

Cerebrovasc Dis 2006;21:38-41

42 进展性卒中: 梗塞本身机制与全身因素的比较 
Stroke-in-Evolution: Infarct-Inherent Mechanisms versus Systemic Causes

Karepov, V.G. ; Gur, A.Y. ; Bova, I. ; Aronovich, B.D. ; Bornstein, N.M.

Cerebrovasc Dis 2006;21:42-46

\section{7 岛叶受损与 QT 间期延长有关：急性卒中患者的心电图异常}

Insular Involvement Is Associated with QT Prolongation: ECG Abnormalities in Patients with Acute Stroke Tatschl, C. ; Stöllberger, C. ; Matz, K. ; Yilmaz, N. ; Eckhardt, R. ; Nowotny, M. ; Dachenhausen, A. ; Brainin, M.

Cerebrovasc Dis 2006;21:47-53

\section{4 卒中后顽外动脉血流量在判断功能预后方面的潜在价值}

Potential Value of Poststroke Extracranial Arterial Blood Flow Volume in the Prediction of Stroke Functional Outcome

Ho, S.S.Y. ; Lam, W.W.M. ; Wong, K.S. ; Leung, C.S.F. ; Metreweli, C.

Cerebrovasc Dis 2006;21:54-59

60 近期动脉血栓形成性缺血卒中患者的相关动脉血栓的定位和治疗：DETECT 调查结果

Detection and Management of Associated Atherothrombotic Locations in Patients with a Recent

Atherothrombotic Ischemic Stroke: Results of the DETECT Survey

Leys, D. ; Woimant, F. ; Ferrières, J. ; Bauters, C. ; Touboul, P.-

J. ; Guérillot, M. ; Herrmann, M.A. ; Priollet, P. ; on behalf of the DETECT investigators,

Cerebrovasc Dis 2006;21:60-66

67 可溶性细胞间黏附分子 1 与缺血卒中患者神经功能恶化的相关性：重庆卒中研究

Association of Soluble Intercellular Adhesion Molecule 1 with Neurological Deterioration of Ischemic Stroke: The Chongqing Stroke Study

Wang, J.Y.J. ; Zhou, D.H.D. ; Li, J. ; Zhang, M. ; Deng, J. ; Gao, C. ; Li, J. ; Lian, Y. ; Chen, M.

Cerebrovasc Dis 2006;21:67-73

74 经颖多普勒超声检测到分流变化与急性大脑中动脉梗塞患者更好的预后相关

Flow Diversion in Transcranial Doppler Ultrasound Is Associated with Better Improvement in Patients with Acute Middle Cerebral Artery Occlusion

Kim, Y.S. ; Meyer, J.S. ; Garami, Z. ; Molina, C.A. ; Pavlovic, A.M. ; Alexandrov, A.V.

Cerebrovasc Dis 2006;21:74-78

79 恶性缺血性卒中患者单侧炒骨切除术伴亚低温治疗与单纯单侧颓骨切除术的安全性及有效性对比 Safety and Therapeutical Benefit of Hemicraniectomy Combined with Mild Hypothermia in Comparison with Hemicraniectomy Alone in Patients with Malignant Ischemic Stroke

Els, T. ; Oehm, E. ; Voigt, S. ; Klisch, J. ; Hetzel, A. ; Kassubek, J.

Cerebrovasc Dis 2006;21:79-85

86 急性缺血性卒中患者颈动脉和经顽联合超声检查结果与临床分级及卒中严重度比较

Combined Carotid and Transcranial Ultrasound Findings Compared with Clinical Classification and Stroke Severity in Acute Ischemic Stroke

Thomassen, L. ; Waje-Andreassen, U. ; Naess, H. ; Aarseth, J. ; Russell, D.

Cerebrovasc Dis 2006;21:86-90

\section{1 接受 CT 检查的中国患者妙内动脉钙化出现的频率及影响因素}

The Frequency and Determinants of Calcification in Intracranial Arteries in Chinese Patients Who Underwent Computed Tomography Examinations

Chen, X. ; Lam, W.W.M. ; Ng, H.K. ; Fan, Y. ; Wong, K.S.

Cerebrovasc Dis 2006;21:91-97 
98 双嘧哒莫可降低阿司匹林抵抗的卒中患者蛋白酶激活受体及膜联蛋白 V 与血小板的结合 Dipyridamole Decreases Protease-Activated Receptor and Annexin-V Binding on Platelets of Poststroke Patients with Aspirin Nonresponsiveness

Serebruany, V. ; Malinin, A. ; Ziai, W. ; Atar, D. ; Pokov, A. ; Jilma, B. ; Hanley, D.

Cerebrovasc Dis 2006;21:98-105

106 甘氨酸拮抗物加维斯替䒺对急性卒中患者脑梗塞区的作用, 一项随机安慰剂对照试验: GAIN MRI 研究

Effect of the Glycine Antagonist Gavestinel on Cerebral Infarcts in Acute Stroke Patients, a Randomized Placebo-Controlled Trial: The GAIN MRI Substudy

Warach, S. ; Kaufman, D. ; Chiu, D. ; Devlin, T. ; Luby, M. ; Rashid, A. ; Clayton, L. ; Kaste, M. ; Lees, K.R. ; Sacco, R. ; Fisher, M. ; for the GAIN Americas and GAIN International MRI Investigators,

Cerebrovasc Dis 2006;21:106-111

112 冠状动脉和脑动脉粥样硬化的关系: 颖外动脉与抄内动脉的区别

Correlation of Coronary and Cerebral Atherosclerosis: Difference between Extracranial and Intracranial

Arteries

Bae, H.-J. ; Yoon, B.-W. ; Kang, D.-W. ; Koo, J.-S. ; Lee, S.-H. ; Kim, K.-B. ; Lee, J. ; Roh, J.-K.

Cerebrovasc Dis 2006;21:112-119

120 地西泮改善急性卒中预后：卒中试验的 GABA 能早期激活研究结果

Diazepam to Improve Acute Stroke Outcome: Results of the Early GABA-Ergic Activation Study In Stroke

Trial

Lodder, J. ; van Raak, L. ; Hilton, A. ; Hardy, E. ; Kessels, A. ; on behalf of the EGASIS Study Group,

Cerebrovasc Dis 2006;21:120-127

128 泰国卒中患者护理人员：他们是谁，他们需要什么

Thai Stroke Patient Caregivers: Who They Are and What They Need

Jullamate, P. ; de Azeredo, Z. ; Pául, C. ; Subgranon, R. ;

Cerebrovasc Dis 2006;21:128-133

\section{基础科学新近报道 Recent Contributions from the Basic Sciences}

134 常压氧治疗-有望延长急性卒中治疗窗的方法

Normobaric Hyperoxia - A Promising Approach to Expand the Time Window for Acute Stroke Treatment

Henninger, N. ; Fisher, M.

Cerebrovasc Dis 2006;21:134-136

137 神经血管单元与星形胶质细胞在脑血流调节中的关键作用

The Neurovascular Unit and the Key Role of Astrocytes in the Regulation of Cerebral Blood Flow

Allan, S.

Cerebrovasc Dis 2006;21:137-138

病例报告 Case Reports

139 孤立的中脑背侧梗塞: 纯感觉卒中的一个少见病因

Isolated Dorsal Midbrain Infarct: An Uncommon Cause of Pure Sensory Stroke

Tsivgoulis, G. ; Spengos, K. ; Vassilopoulou, S. ; Zakopoulos, N. ; Zis, V.

Cerebrovasc Dis 2006;21:139-140

140 美容厅卒中综合征 
Beauty Parlor Stroke Syndrome

Heckmann, J.G. ; Heron, P. ; Kasper, B. ; Dörfler, A. ; Maihöfner, C.

Cerebrovasc Dis 2006;21:140-141

142 表现为垂体卒中的嵌于垂体粗腺瘤内的颈动脉海绵窦段巨大动脉瘤

A Giant Intracavernous Carotid Artery Aneurysm Embedded in Pituitary Macroadenoma Presenting with Pituitary Apoplexy

Chuang, C.C. ; Chen, Y.L. ; Pai, P.C. ;

Cerebrovasc Dis 2006;21:142-144 